\title{
Pelatihan Pengolahan Makanan Sehat Ibu-Ibu PKK Kelurahan Bulu Lor Semarang Utara
}

\author{
Sasono Wibowo ${ }^{1}$, Indra Gamayanto ${ }^{2}$, \\ ${ }^{1,2}$ Fakultas Ilmu Komputer, Departemen Sistem Informasi, Universitas Dian Nuswantoro \\ E-mail: ${ }^{1}$ sasono.wibowo@dsn.dinus.ac.id, ${ }^{2}$ indra.gamayanto@dsn.dinus.ac.id,
}

\begin{abstract}
Abstrak
Dengan banyaknya bidang usaha bisnis, terutama makanan cepat saji yang sangat menjamur kadangkala mengakibatkan ibu ibu lebih senang beli makanan yang sudah siap, karena praktis tidak repot belanja, memasak dan lain lain. Apalagi di era semua serba elektronik dimana cara berbelanja semakin mudah dan praktis, banyak beberapa pengusaha makanan yang cara pemasaranya dengan menggunakan media elektronik, seperti gofood, akan semakin membuat kita khususnya ibu ibu yang relative sibuk lebih memilih menggunakan jasa gofood. Yang kita tidak tau pasti bagaimana kebersihan maupun kandungan gizi yang ada berkaitan dengan cara memasaknya. Berdasarkan analisis situasi dan identifikasi masalah tersebut diatas, maka dapat dirumuskan sebuah permasalahan yaitu bagaimana cara memberikan pelatihan pengolahan makanan yang sehat dan murah agar kebutuhan gizi dan kesehatan tetap terjaga. Hasil dari pengabdian masyarakat ini adalah ibu-ibu PKK Kelurahan Bulu Lor Semarang Utara dapat memahami bagaimana cara menyimpan, mengelola dan mempertahankan gizi pada makanan sehingga hal tersebut akan dapat menjaga kesehatan dan dapat meningkatkan kesehatan di masa yang akan datang. Pengabdian masyarakat ini akan terus berlangsung dan akan terdapat kegiatan-kegiatan lain yang berhubungan dengan kesehatan dan peningkatan gizi bagi Kelurahan Bulu Lor Semarang Utara. Hal ini diperlukan untuk meningkatkan pola hidup di sehat pada masyarakat khususnya Kelurahan Bulu Lor Semarang Utara
\end{abstract}

Kata kunci: Pelatihan, Kelurahan Bulu Lor, Makanan Sehat, Pengolahan, PKK

\section{Abstract}

With so many business fields, especially fast food, which is very widespread, sometimes it results in mothers preferring to buy ready-made food, because they practically don't bother shopping, cooking and so on. Especially in an era of all electronics where shopping is easier and more practical, there are many food entrepreneurs whose marketing methods are using electronic media, such as gofood, which will increasingly make us, especially mothers who are relatively busy, prefer to use gofood services. What we don't know for sure is how the cleanliness and nutritional content are related to how to cook it. Based on the situation analysis and identification of the problems mentioned above, a problem can be formulated, namely how to provide training in healthy and inexpensive food processing so that nutritional and health needs are maintained. The result of this community service is that the women of PKK Kelurahan Bulu Lor North Semarang can understand how to store, manage and maintain nutrition in food so that it can maintain health and can improve health in the future. This community service will continue and there will be other activities related to health and nutrition improvement for Bulu Lor Village, North Semarang. This is necessary to improve a healthy lifestyle in the community, especially Bulu Lor Village, North Semarang

Keywords: Training, Bulu Lor Village, Healthy Food, Processing, PKK 


\section{PENDAHULUAN}

Dengan banyaknya bidang usaha bisnis, terutama makanan cepat saji yang sangat menjamur kadangkala mengakibatkan ibu ibu lebih senang beli makanan yang sudah siap, karena praktis tidak repot belanja, memasak dan lain lain. Apalagi di era semua serba elektronik dimana cara berbelanja semakin mudah dan praktis, banyak beberapa pengusaha makanan yang cara pemasaranya dengan menggunakan media elektronik, seperti gofood, akan semakin membuat kita khususnya ibu ibu yang relative sibuk lebih memilih menggunakan jasa gofood. Yang kita tidak tau pasti bagaimana kebersihan maupun kandungan gizi yang ada berkaitan dengan cara memasaknya. Berdasarkan analisis situasi dan identifikasi masalah tersebut diatas, maka dapat dirumuskan sebuah permasalahan yaitu bagaimana cara memberikan pelatihan pengolahan makanan yang sehat dan murah agar kebutuhan gizi dan kesehatan tetap terjaga. Peningkatan pemahaman dan kemampuan berbelanja, menyimpan dan mengolah makanan yang sehat dan aman untuk meningkatkan kesehatan warga kelurahan Bulu Lor Semarang, Kecamatan Semarang Utara.

Makan makanan yang sehat bukanlah tentang batasan yang ketat, tetapi lebih kepada bagaimana kita mengontrol makan makanan yang kita kosumsi. Makan manakan yang sehat adalah tentang bagaimana menjadi lebih baik, memiliki lebih banyak energi, meningkatkan kesehatan, dan meningkatkan suasana hati. Makan sehat tidak harus terlalu rumit. Jika kita merasa kewalahan dengan semua nutrisi yang bertentangan dan saran diet di luar sana, kita tidak sendiri. Tampaknya untuk setiap ahli yang memberi tahu kita tentang makanan tertentu yang baik untuk kita. Kita akan menemukan pepatah lain yang justru sebaliknya. Yang benar adalah bahwa sementara beberapa makanan atau nutrisi tertentu terbukti memiliki efek menguntungkan pada suasana hati, pola diet kita secara keseluruhan yang paling penting. Lkitasan pola makan yang sehat adalah mengganti makanan olahan dengan makanan sungguhan jika memungkinkan. Makan makanan yang sedekat mungkin dengan cara alam membuatnya dapat membuat perbedaan besar pada cara kita berpikir, melihat, dan merasakan. Sementara beberapa diet ekstrim mungkin menyarankan sebaliknya, kita semua membutuhkan keseimbangan protein, lemak, karbohidrat, serat, vitamin, dan mineral dalam makanan kita untuk menopang tubuh yang sehat. Kita tidak perlu menghilangkan kategori makanan tertentu dari diet kita, melainkan memilih opsi paling sehat dari setiap kategori, antara lain: (1) Protein memberi kita energi untuk bangkit dan pergi — dan terus maju — sambil juga mendukung suasana hati dan fungsi kognitif. Terlalu banyak protein bisa berbahaya bagi penderita penyakit ginjal, tetapi penelitian terbaru menunjukkan bahwa banyak dari kita membutuhkan lebih banyak protein berkualitas tinggi, terutama seiring bertambahnya usia. Itu tidak berarti kita harus makan lebih banyak produk hewani - berbagai sumber protein nabati setiap hari dapat memastikan tubuh kita mendapatkan semua protein esensial yang dibutuhkannya, (2) Gemuk. Tidak semua lemak itu sama. Sementara lemak jahat dapat merusak pola makan kita dan meningkatkan risiko penyakit tertentu, lemak baik melindungi otak dan jantung kita. Faktanya, lemak sehat - seperti omega3 - sangat penting untuk kesehatan fisik dan emosional kita. Memasukkan lebih banyak lemak sehat dalam makanan kita dapat membantu meningkatkan suasana hati kita, meningkatkan kesejahteraan kita, dan bahkan memangkas lingkar pinggang kita, (3) Serat. Makan makanan tinggi serat makanan (biji-bijian, buah, sayuran, kacang-kacangan, dan kacang-kacangan) dapat membantu kita tetap teratur dan menurunkan risiko penyakit jantung, stroke, dan diabetes. Itu juga dapat memperbaiki kulit kita dan bahkan membantu kita menurunkan berat badan, (4) Kalsium. Selain menyebabkan osteoporosis, tidak mendapatkan cukup kalsium dalam makanan kita juga dapat menyebabkan kecemasan, depresi, dan kesulitan tidur. Berapapun usia atau jenis kelamin kita, penting untuk memasukkan makanan kaya kalsium ke dalam makanan kita, membatasi makanan yang menghabiskan kalsium, dan mendapatkan cukup magnesium dan vitamin $\mathrm{D}$ dan $\mathrm{K}$ untuk membantu kalsium melakukan tugasnya, (5) Karbohidrat adalah salah satu sumber energi utama tubuh kita. Tetapi sebagian besar harus berasal dari karbohidrat kompleks dan tidak dimurnikan (sayuran, biji-bijian, buah) daripada gula dan karbohidrat olahan. Mengurangi roti putih, kue kering, pati, dan gula dapat mencegah lonjakan cepat gula 
darah, fluktuasi suasana hati dan energi, dan penumpukan lemak, terutama di sekitar lingkar pinggang kita.

Beralih ke diet sehat tidak harus menjadi proposisi semua atau tidak sama sekali. kita tidak harus menjadi sempurna, kita tidak harus sepenuhnya menghilangkan makanan yang kita sukai, dan kita tidak harus mengubah semuanya sekaligus - yang biasanya hanya mengarah pada menyerah pada rencana makan baru kita. Pendekatan yang lebih baik adalah membuat beberapa perubahan kecil dalam satu waktu. Menjaga tujuan Kita tetap sederhana dapat membantu Kita mencapai lebih banyak dalam jangka panjang tanpa merasa kehilangan atau kewalahan oleh perombakan diet besar-besaran. Bayangkan perencanaan diet sehat sebagai sejumlah langkah kecil yang dapat dikelola - seperti menambahkan salad ke dalam diet Kita sekali sehari. Saat perubahan kecil menjadi kebiasaan, Kita dapat terus menambahkan pilihan yang lebih sehat.

\section{METODE}

Metode kegiatan yang dianggap tepat untuk menyelesaikan masalah tersebut adalah Ceramah, diskusi dan pelatihan yang meliputi tutorial dan praktek memasak secara langsung. Kegiatan pelatihan ini dilaksanakan dalam dua kegiatan terprogram yaitu:

Kegiatan 1: Pelatihan di Balai Kelurahan Bulu Lor - Metode pelatihan yang digunakan adalah metode ceramah dan tutorial.

Tabel 1 Tabel Jadwal Pelaksanaan Kegiatan

\begin{tabular}{|l|l|c|}
\hline \multicolumn{1}{|c|}{ Waktu } & \multicolumn{1}{|c|}{ Kegiatan } & Pelaksana \\
\hline 16 Juli 2019-27 Juli 2019 & $\begin{array}{l}\text { Konfirmasi dengan Mitra untuk } \\
\text { persiapan materi IbM }\end{array}$ & Tim Pengabdian \\
\hline 6 Agustus 2019 & Pelaksanaan IbM & Tim Pengabdian \\
\hline 9 Agustus 2019 & $\begin{array}{l}\text { Penyusunan Laporan IbM dan } \\
\text { konsultasi }\end{array}$ \\
\hline
\end{tabular}

Kegiatan 2: Konsultasi

Pada tahap konsultasi, peserta diberikan kesempatan untuk melakukan konsultasi dengan tim pengabdian untuk kosultasi dan diskusi mengenai hasil sosialisasi dan pelatihan cara masak sehat dengan tim pengabdian Universitas Dian Nuswantoro, adapun konsultasi bisa dilaksanakan dengan media komunikasi via telepon atau media yang lain

Tabel 2 Tahapan, Kegiatan dan Kegunaan dalam pengabdian

\begin{tabular}{|c|c|c|}
\hline Tahapan & Kegiatan & Kegunaan dalam pengabdian \\
\hline 1 & $\begin{array}{l}\text { Persiapan } \\
\text { 1. Sosialisasi dan publikasi rencana } \\
\text { pelaksanaan pengabdian dengan sasaran. } \\
\text { 2. Penyusunan modul pelatihan } \\
\text { 3. } \\
\text { Menyiapkan materi dan peralatan } \\
\text { pendukung }\end{array}$ & $\begin{array}{l}\text { 1. Mendapatkan peserta pelatihan. } \\
\text { 2. Menyiapkan modul pelatihan. } \\
\text { 3. Bahan, alat dan modul pelatihan sesuai } \\
\text { dengan kebutuhan }\end{array}$ \\
\hline 2. & $\begin{array}{l}\text { Pelaksanaan pelatihan: } \\
\text { 1. Pelatihan dilakukan bawah bimbingan } \\
\text { ahli gizi } \\
\text { 2. Pembimbingan melalui konsultasi }\end{array}$ & $\begin{array}{l}\text { 1. Peserta mendapatkan pengetahuan } \\
\text { tentang jenis-jenis bahan makanan dan } \\
\text { cara memasak yang baik }\end{array}$ \\
\hline 3. & Monitoring dan Evaluasi & $\begin{array}{l}\text { Mengevaluasi seluruh kegiatan serta } \\
\text { menyempurnakannya berdasarkan } \\
\text { masukan-masukan dari berbagai pihak. }\end{array}$ \\
\hline 4. & $\begin{array}{l}\text { Penyusunan laporan pelaksanaan kegiatan } \\
\text { pengabdian }\end{array}$ & Laporan kegiatan tersusun dengan baik. \\
\hline
\end{tabular}

Faktor pendukug keberhasilan dalam kegiatan ini adalah sebagai berikut:

1. Pemilihan waktu yang tepat untuk melaksanakan kegiatan. kegiatan dilaksanakan pada bulan Juli 2019 sampai dengan bulan Agustus 2019 
2. Keinginan yang kuat dari Staff pegawai kelurahan Bulu Lor dan ibu ibu Penggerak PKK untuk mengetahui dan bisa mengolah makanan yang sehat dengan baik.

\section{HASIL DAN PEMBAHASAN}

Makan sehat berarti makan berbagai makanan yang memberi Kita nutrisi yang dibutuhkan untuk menjaga kesehatan, merasa nyaman, dan berenergi. Nutrisi tersebut antara lain protein, karbohidrat, lemak, air, vitamin, dan mineral.

\subsection{Buah-buahan dan sayur-sayuran}

Diet kaya buah dan sayuran direkomendasikan oleh para ahli kanker serta ahli diet terdaftar. The American Cancer Society dan American Institute for Cancer Research merekomendasikan makan 5 porsi atau lebih berbagai sayuran dan buah-buahan setiap hari untuk memastikan bahwa risiko kanker Kita serendah mungkin. The United States Department of Agriculture (USDA) 2015-20 Dietary Guidelines for American merekomendasikan sekitar 3 cangkir sayuran per hari dan 2 cangkir buah per hari untuk wanita (untuk pria rekomendasinya adalah 4 cangkir sayuran dan 2,5 cangkir buah). Pakar gizi mengatakan bahwa variasi adalah kuncinya, karena buah dan sayur yang berbeda memiliki gizi yang berbeda pula. Ditambah lagi, jika Kita makan terlalu banyak satu hal, Kita mungkin bosan. Salah satu cara menyantap aneka buah dan sayur adalah dengan mengonsumsi makanan dengan segala warna pelangi. Hijau adalah brokoli. Merah adalah paprika. Kuning adalah pisang. Ungu adalah terong. Jeruk adalah jeruk. Atau cobalah makan sayuran hijau tua (bayangkan bayam, collard hijau, atau kangkung) pada satu kali makan, dan jeruk (wortel, ubi jalar, atau labu) pada saat berikutnya. Potong apel menjadi sereal pagi Kita dan nikmati buah persik dengan makan siang Kita. Raspberry beku atau blackberry adalah makanan penutup yang enak[1],[2],[3]

\subsection{Biji-bijian utuh}

Pedoman USDA merekomendasikan 3 hingga 4 ons atau lebih biji-bijian per hari untuk wanita ( 3 hingga 5 ons untuk pria). Biji-bijian utuh masih memiliki dedak dan kuman (inti dari biji-bijian) yang menempel dan memiliki lebih banyak serat, mineral, dan vitamin daripada bijibijian olahan. Proses pemurnian menghilangkan dedak dan kuman dari biji-bijian[4]. Kita tidak dapat mengetahui apakah suatu makanan terbuat dari biji-bijian dengan melihat warnanya - Kita harus membaca labelnya. Bahannya harus mengatakan "whole grain" atau "whole grain" sebelum nama bulirnya, "whole grain wheat" misalnya. Nasi merah, bulgur, oatmeal, dan barley adalah contoh biji-bijian yang dimakan sendiri. Baik American Institute for Cancer Research dan American Cancer Society merekomendasikan untuk memilih biji-bijian daripada biji-bijian olahan. Agar dianggap tinggi biji-bijian, roti harus memiliki 2 hingga 3 gram serat per irisan, dan sereal harus memiliki setidaknya 6 gram atau lebih serat per porsi. Beberapa contohnya adalah sereal Multi-Bran Chex oleh General Mills (7 gram serat per porsi) dan sereal Flax and Fiber Crunch oleh Back to Nature (9 gram serat per porsi)[5],[6],[7].

\subsection{Makanan berprotein (daging, ikan, unggas, telur, kacang-kacangan)}

Daging adalah sumber protein dan asam lemak yang Kita butuhkan untuk energi dan kesehatan. Daging merah juga mengandung zat besi, yang sangat penting bagi wanita. Pedoman USDA merekomendasikan makan 7 ons makanan berprotein per hari[8]. Jika Kita memang makan daging, unggas, atau ikan, cobalah untuk memilih potongan tanpa lemak dan lebih sering memilih ayam atau ikan. Jika Kita tidak makan daging, Kita mungkin perlu menambahkan kacang-kacangan, biji-bijian, kacang-kacangan, atau produk kedelai ke dalam makanan Kita untuk memastikan Kita mendapatkan cukup protein dan zat besi. Telur juga termasuk dalam kategori ini. Satu telur sama dengan 1 ons daging[9]

\subsection{Susu dan produk susu}

USDA merekomendasikan agar Kita makan 3 cangkir setara makanan olahan susu setiap hari. Bisa jadi: 3 cangkir susu, susu kedelai yang diperkaya, atau yogurt (itu lebih dari 
tiga wadah yogurt 6 ons) dan 4,5 ons keju alami, seperti cheddar (sekitar empat potong). USDA juga merekomendasikan untuk memilih versi produk susu yang bebas lemak atau rendah lemak. Jika Kita tidak suka atau tidak bisa minum susu atau produk susu, pastikan Kita mendapatkan cukup fosfor, vitamin A, kalsium, dan vitamin D dari sumber makanan lain. Contohnya termasuk wortel, ubi jalar, labu musim dingin, brokoli, sayuran berdaun hijau tua, salmon, sarden, dan sereal yang diperkaya. Jika Kita tidak toleran laktosa, Kita mungkin ingin mencoba suplemen laktase atau susu bebas laktosa. Kita juga bisa memilih susu kedelai atau almond[10].

\subsection{Lemak dan minyak}

Kita membutuhkan lemak dalam makanan Kita, tetapi tidak terlalu banyak. Pedoman USDA merekomendasikan untuk mengonsumsi sekitar 30 gram lemak per hari. Pedoman tersebut juga merekomendasikan agar Kita mendapatkan tidak lebih dari 10\% kalori harian Kita dari lemak jenuh[11],[12].

Ada dua jenis lemak utama:

1. Lemak jenuh ditemukan dalam produk hewani seperti susu murni, keju, es krim, daging berlemak, dan beberapa minyak nabati, seperti minyak sawit dan minyak kelapa. Lemak jenuh juga termasuk lemak trans, ditemukan dalam shortening, stick (atau hard) margarin, cookies, cracker, makanan ringan, gorengan, donat, kue kering, makanan yang dipanggang, dan makanan olahan lainnya yang dibuat dengan atau digoreng dengan minyak terhidrogenasi parsial[13],[12].

2. Lemak tak jenuh tunggal dan lemak tak jenuh gkita ditemukan pada ikan dan banyak makanan dari tumbuhan seperti sayuran, kacang-kacangan, dan biji-bijian, serta minyak yang dibuat dari kacang-kacangan dan biji-bijian (kanola, jagung, kedelai)[14],[12].

Makanan nabati seperti sayuran, buah-buahan, biji-bijian, polong-polongan, kacangkacangan, dan biji-bijian menyediakan vitamin, mineral, dan senyawa nabati lainnya yang memiliki efek perlindungan kanker[15]. Mereka juga menyediakan serat, yang melindungi dari kanker kolorektal. Kebanyakan makanan nabati dalam bentuk alami lebih rendah kalori daripada banyak makanan lainnya. Makan sebagian besar makanan nabati untuk memenuhi kebutuhan nutrisi Kita dapat memuaskan rasa lapar sekaligus membuatnya lebih mudah untuk mempertahankan berat badan yang sehat. Jadikan makanan nabati sebagai fokus makanan dan camilan Kita. Makanan dengan jumlah gula tambahan yang tinggi memicu hati untuk membuang lemak dalam jumlah tinggi ke dalam aliran darah[16]. Selain itu, diet tinggi gula dapat menyebabkan resistensi insulin di jaringan, sehingga mengganggu sistem endokrin. Makanan ini dapat menambah berat badan ekstra pada tubuh Kita, melemahkan tulang Kita dan membuat organ Kita bekerja lebih keras. Ini membuat Kita rentan terhadap berbagai masalah kesehatan di masa mendatang. Sumber gula tambahan terbesar dalam makanan Amerika adalah dalam bentuk makanan olahan. Selain itu, penelitian baru telah muncul yang menghubungkan diet tinggi makanan olahan dengan tingkat kanker yang lebih tinggi bagaimana makan sehat mencegah penyakit. Mungkin bahan kimia tambahan dan aditif makanan yang meningkatkan umur simpan produk ini secara tidak perlu membuat tubuh terpapar karsinogen potensial[17]. Contoh makanan olahan dan makanan tinggi gula tambahan meliputi:

1. makanan praktis seperti kebanyakan sup mie instan dan pizza beku

2. makanan yang dipanggang seperti kue, biskuit, muffin, donat

3. camilan manis dan asin

4. minuman manis

Makan terlalu banyak daging merah (sapi, babi, dan domba) meningkatkan risiko kanker kolorektal. Sedikit daging merah masih bisa menjadi bagian dari pola makan yang sehat. Daging merupakan sumber zat besi, protein, vitamin B12, dan seng yang baik. Jika Kita memasukkan daging merah, batasi jumlah yang Kita makan tidak lebih dari 500 gram (18 ons) per minggu. Daging olahan, seperti ham, bacon, sosis, salami, hot dog, pepperoni, dan banyak 
daging deli meningkatkan risiko kanker kolorektal dan perut. Jika Kita memilih untuk makan daging ini, makanlah dalam jumlah kecil dan lebih jarang[18].

Pentingnya aktivitas fisik dalam menjaga dan meningkatkan kesehatan tidak bisa dilebih-lebihkan. Gaya hidup sehat dan aktif akan menurunkan risiko penyakit kronis seperti diabetes, hipertensi, osteoporosis, stroke, dan kanker tertentu. Selain itu, aktivitas fisik yang kuat secara teratur memiliki efek menguntungkan pada suasana hati, dan telah terbukti bermanfaat memengaruhi depresi, kecemasan, dan insomnia. Pola makan sehat dan gaya hidup aktif dapat membantu Kita memiliki tubuh yang sehat

Pelaksanaan Pengabdian Masyarakat yang dilakukan yaitu berupa pelatihan pengolahan makanan sehat bagi ibu ibu PKK Kelurahan Bulu Lor Semarang Kecamatan Semarang Utara. Adapun kegiatan tersebut meliuti :

1. Menentukan tempat berbelanja yang aman dan bersih

2. Menyusun Menu sehari hari yang sehat

3. Menyimpan sayuran maupun makanan yang sehat

4. Memasak (mengukus, menggoreng, membakar) yang sehat

5. Konsultasi selama pelatihan untuk membahas permasalahan yang timbul dalam pelatihan dilakukan secara berkelompok dengan bimbingan tim pengabdian. Peserta pelatihan dapat berkonsultasi selama pelatihan berlangsung.

Dokumentasi kegiatan tersebut, antara lain:

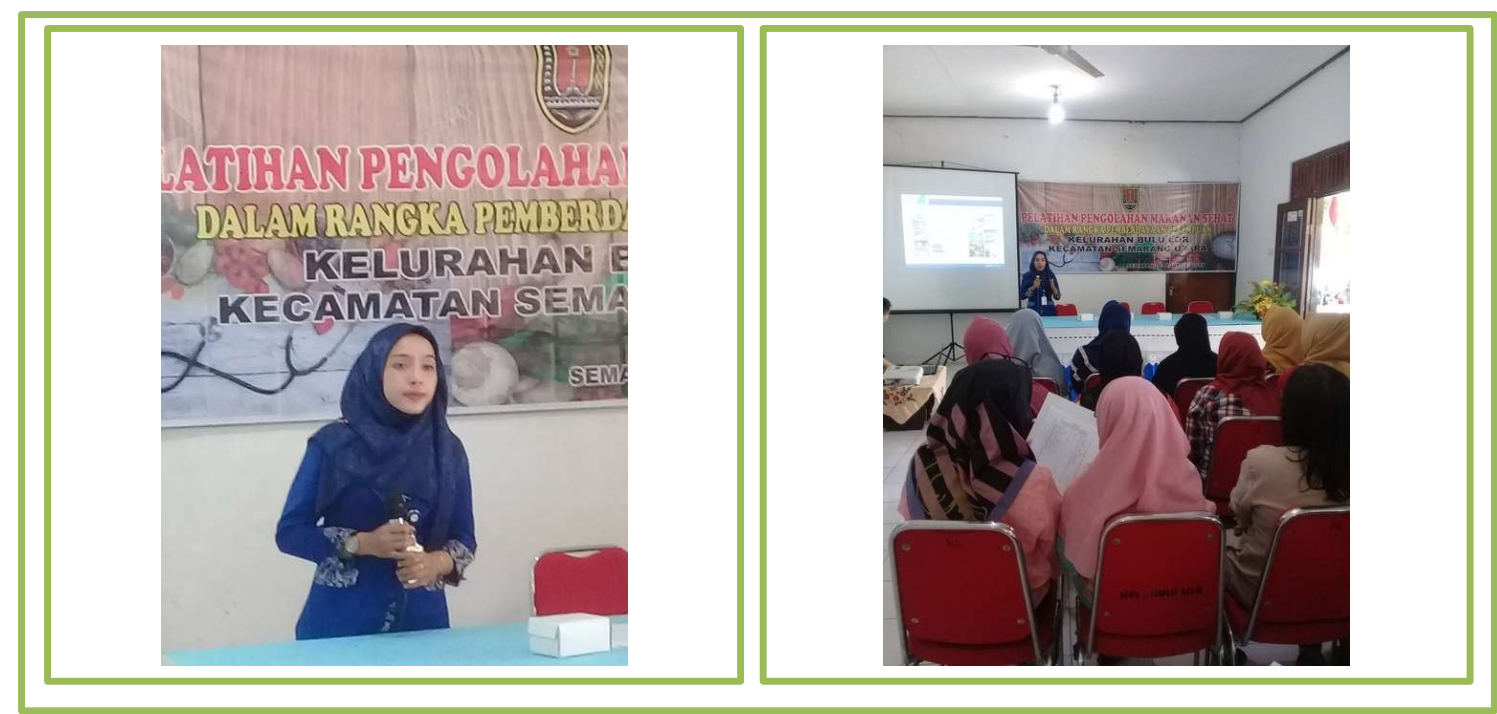

Gambar 2 Kegiatan dan ceramah session 1 


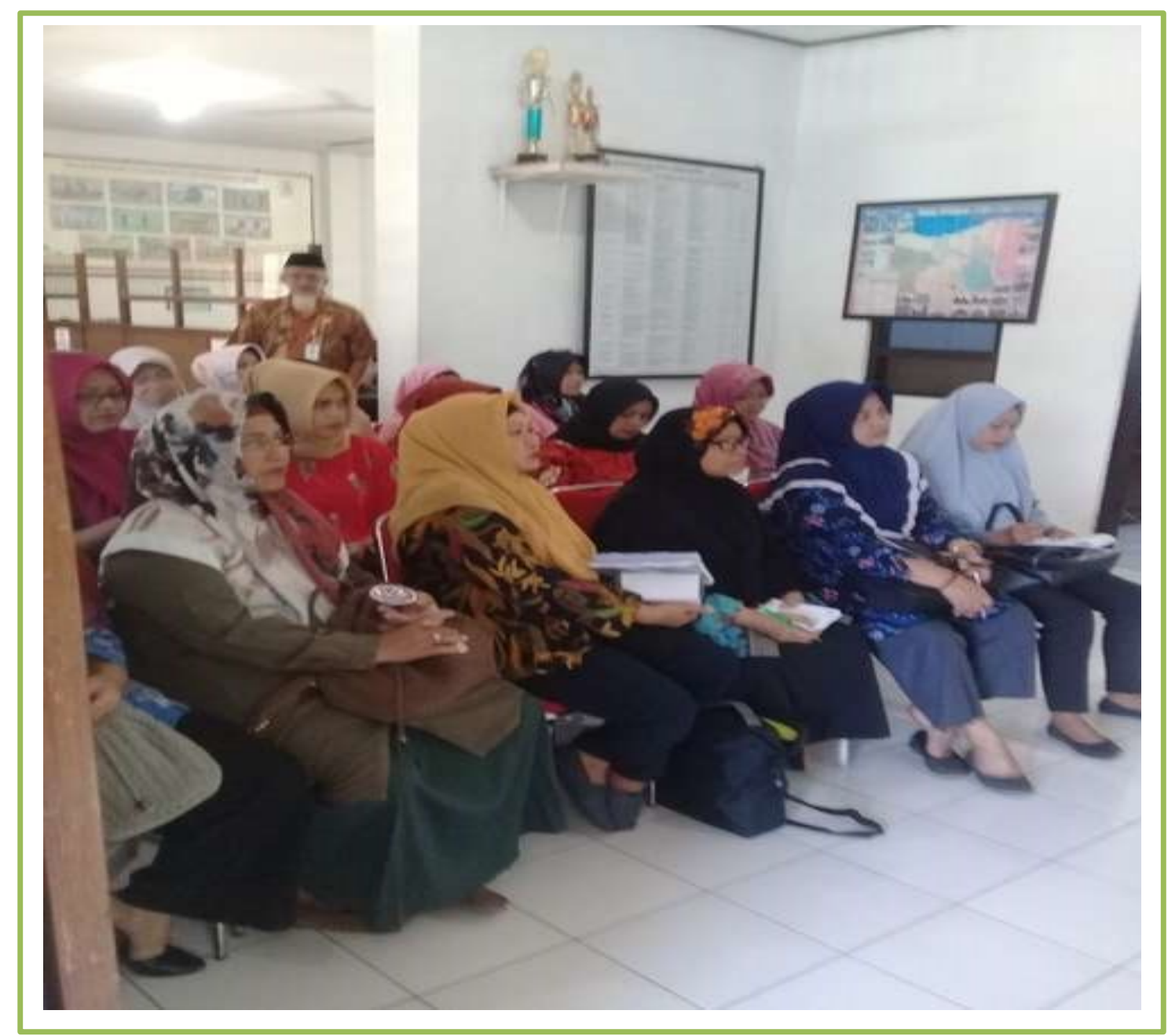

Gambar 3 Kegiatan dan ceramah session 2

Untuk mempersiapkan diri Kita agar sukses, usahakan untuk tetap sederhana. Makan makanan yang lebih sehat tidak harus rumit. Daripada terlalu memikirkan menghitung kalori, misalnya, pikirkan diet Kita dalam kaitannya dengan warna, variasi, dan kesegaran. Berfokuslah untuk menghindari makanan kemasan dan olahan dan memilih bahan-bahan yang lebih segar jika memungkinkan. Siapkan lebih banyak makanan Kita sendiri . Memasak lebih banyak makanan di rumah dapat membantu Kita mengontrol apa yang Kita makan dan memantau dengan lebih baik apa yang masuk ke dalam makanan Kita. Kita akan makan lebih sedikit kalori dan menghindari zat tambahan kimiawi, tambahan gula, dan lemak tidak sehat dari makanan kemasan dan makanan yang dibawa pulang yang dapat membuat Kita merasa lelah, kembung, dan mudah tersinggung, serta memperburuk gejala depresi, stres, dan kecemasan. Lakukan perubahan yang tepat. Saat mengurangi makanan tidak sehat dalam diet Kita, penting untuk menggantinya dengan alternatif yang sehat. Mengganti lemak trans yang berbahaya dengan lemak sehat (seperti mengganti ayam goreng dengan salmon panggang) akan membuat perbedaan positif bagi kesehatan Kita. Namun, mengganti lemak hewani dengan karbohidrat olahan (seperti mengganti bacon sarapan Kita dengan donat), tidak akan menurunkan risiko penyakit jantung atau memperbaiki suasana hati Kita. Fokus pada perasaan Kita setelah makan . Ini akan membantu menumbuhkan kebiasaan dan selera baru yang sehat. 


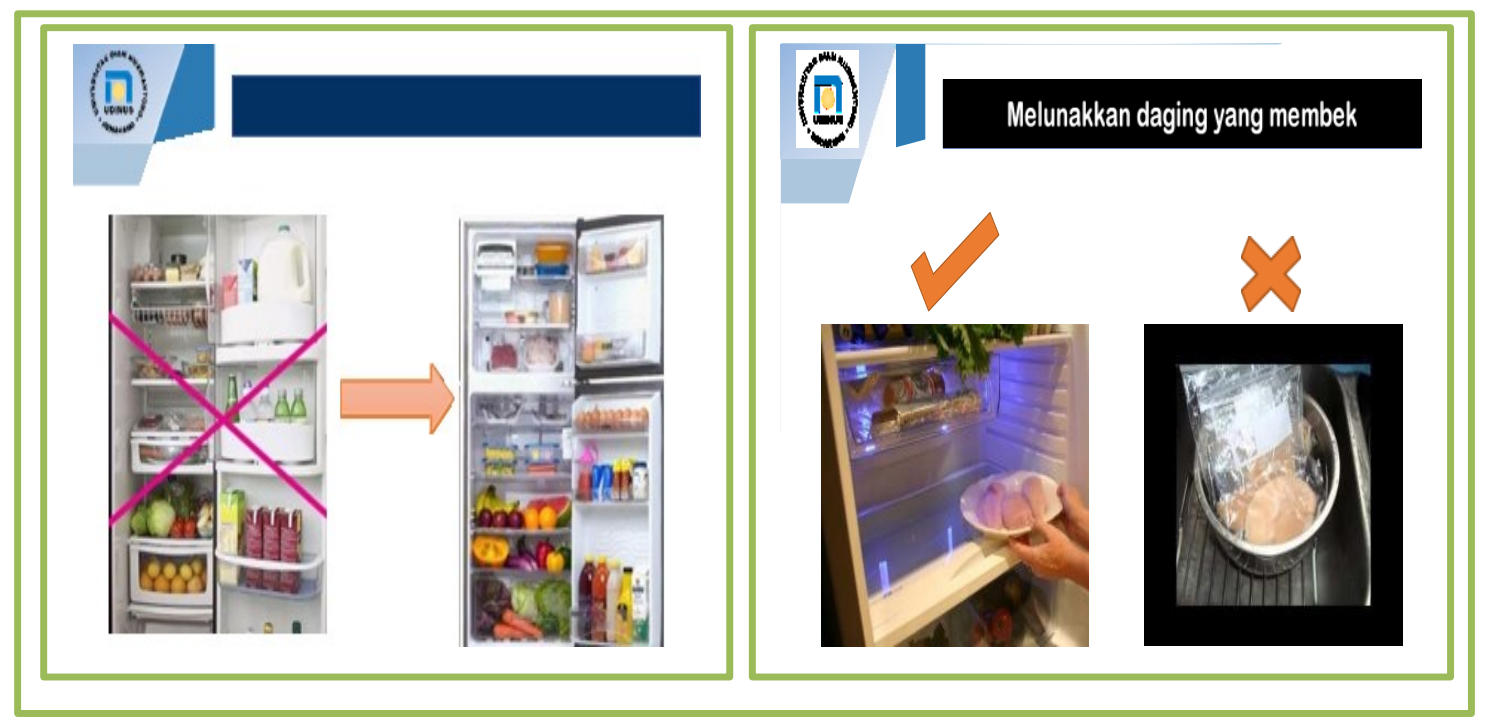

Gambar 4 Slide presentasi

Semakin sehat makanan yang Kita makan, semakin baik perasaan Kita setelah makan. Semakin banyak junk food yang Kita makan, semakin besar kemungkinan Kita merasa tidak nyaman, mual, atau kehabisan energi. Minum banyak air . Air membantu membersihkan sistem produk limbah dan racun kita, namun banyak dari kita yang mengalami dehidrasi dalam hidup - menyebabkan kelelahan, energi rendah, dan sakit kepala. Sering salah mengira haus sebagai lapar, jadi tetap terhidrasi dengan baik juga akan membantu Kita membuat pilihan makanan yang lebih sehat.

Apa itu moderasi? Intinya, itu berarti makan hanya sebanyak yang dibutuhkan tubuh Kita. Kita harus merasa puas di akhir makan, tetapi tidak kenyang. Bagi banyak dari kita, tidak berlebihan berarti makan lebih sedikit dari yang kita lakukan sekarang. Tapi itu tidak berarti menghilangkan makanan yang Kita sukai. Makan daging asap untuk sarapan sekali seminggu, misalnya, dapat dianggap tidak berlebihan jika Kita mengikutinya dengan makan siang dan makan malam yang sehat - tetapi tidak jika Kita mengikutinya dengan sekotak donat dan pizza sosis. Ketika Kita melarang makanan tertentu, wajar jika Kita menginginkan makanan tersebut lebih banyak, dan kemudian merasa gagal jika Kita menyerah pada godaan. Mulailah dengan mengurangi ukuran porsi makanan yang tidak sehat dan tidak sering mengonsumsinya. Saat Kita mengurangi asupan makanan yang tidak sehat, Kita mungkin mendapati diri Kita tidak terlalu menginginkannya atau menganggapnya hanya sebagai kesenangan sesekali. Ukuran porsi telah membengkak akhir-akhir ini. Saat makan di luar, pilih makanan pembuka daripada hidangan utama, bagi hidangan dengan teman, dan jangan memesan apa pun yang berukuran besar. Di rumah, petunjuk visual dapat membantu dengan ukuran porsi. Porsi daging, ikan, atau ayam Kita harus sebesar setumpuk kartu dan setengah cangkir kentang tumbuk, nasi, atau pasta seukuran bola lampu tradisional. Dengan menyajikan makanan Kita di piring atau mangkuk yang lebih kecil, Kita dapat menipu otak untuk berpikir bahwa itu porsi yang lebih besar. Jika Kita tidak merasa puas di akhir makan, tambahkan lebih banyak sayuran hijau atau akhiri makan dengan buah. Penting untuk memperlambat dan berpikir tentang makanan sebagai makanan, bukan hanya sesuatu untuk ditelan di sela-sela rapat atau dalam perjalanan menjemput anak-anak. Sebenarnya dibutuhkan beberapa menit bagi otak Kita untuk memberi tahu tubuh Kita bahwa ia telah memiliki cukup makanan, jadi makanlah perlahan dan berhentilah makan sebelum Kita merasa kenyang. Makan sendirian, terutama di depan TV atau komputer, sering kali menyebabkan makan berlebihan tanpa berpikir. Berhati-hatilah dengan makanan yang Kita simpan. Lebih sulit untuk makan dalam jumlah sedang jika Kita sudah menyiapkan camilan dan 
camilan yang tidak sehat. Alih-alih, kelilingi diri Kita dengan pilihan yang sehat dan ketika Kita siap menghadiahi diri Kita dengan suguhan istimewa, pergilah dan dapatkan kemudian.

Bukan hanya apa yang Kita makan, tetapi saat Kita makan. Makan sarapan, dan makan makanan kecil sepanjang hari . Sarapan yang sehat dapat meningkatkan metabolisme Kita, sementara makan dalam porsi kecil dan makanan sehat membuat energi Kita tetap terjaga sepanjang hari. Hindari makan larut malam . Usahakan makan malam lebih awal dan berpuasa selama 14-16 jam hingga sarapan pagi berikutnya. Studi menunjukkan bahwa makan hanya saat Kita paling aktif dan memberi sistem pencernaan Kita istirahat yang lama setiap hari dapat membantu mengatur berat badan.

\section{KESIMPULAN DAN SARAN}

\subsection{Kesimpulan}

Pelaksanaan Pengabdian Masyarakat dilakukan dengan tujuan untuk :

1. Meningkatkan pengetahuan mengolah makanan secara sehat

2. Meningkatkan kemampuan mengolah berbagai cara memasak jenis sayur yang sehat para Ibu PKK Kelurahan Bulu Lor Semarang untuk bisa menyajikan masakan sederhana tetapi sehat.

3. Meningkatkan motivasi para Ibu Ibu PKK Kelurahan Bulu Lor semarang dalam mengolah berbagai jenis makanan sehat.

\subsection{Saran}

Kegiatan pengabdian kepada masyarakat ini sebaiknya berkesinambungan dan lebih ditingkatkan, khususnya tidak hanya di bidang kesehatan masyarakat saja tetapi juga dibidang yang lain

\section{UCAPAN TERIMA KASIH}

Penulis berterima kasih kepada Kelurahan Bulu Lor dan Mega Mawarti, Amd RMIK, Fakultas Kesehatan, universitas Dian Nuswantoro.

\section{DAFTAR PUSTAKA}

[1] The food trust, Healthy Food Access. 2011, pp. 56-62.

[2] K. Zhang, Q. Li, W. Wu, J. Yang, and W. Zou, "Wheat Qu and Its Production Technology, Microbiota, Flavor, and Metabolites," J. Food Sci., vol. 84, no. 9, pp. 23732386, 2019, doi: 10.1111/1750-3841.14768.

[3] S. R. Kolle and T. H. Shankarappa, "Journal of Food Science and Technology:A Web of Science Based Bibliometric Analysis (2006-2015)," SRELS J. Inf. Manag., vol. 53, no. 4, p. 323, 2016, doi: 10.17821/srels/2016/v53i4/86634.

[4] W. Zhang, R. Tocmo, and K. L. Parkin, "Synergistic effects of Salkenylmercaptocysteine (CySSR) species derived from Allium tissue and selenium on inducing apoptosis in ER- breast cancer cells," J. Funct. Foods, vol. 65, no. December 2019, p. 103786, 2020, doi: 10.1016/j.jff.2020.103786.

[5] A. O. Shalaby, "Exploring the Benefits and Advancements in Nutrition and Health Care," J. Food Nutr. Heal., vol. 3, no. 1, pp. 3-4, 2020.

[6] A. M. Combo, P. A. Dakia, O. Hugues, and J. Gildas, "Antinutrients, Mineral and Bioavailability Prediction of Calcium and Iron in Eggplant Fruit ( Solanum spp .) Varieties Consumed in Côte d' Ivoire," vol. 10, no. 2, pp. 43-48, 2020, doi: 10.5923/j.food.20201002.01.

[7] M. Al-Ghazali, I. Al-Bulushi, L. Al-Subhi, M. S. Rahman, and A. Al-Rawahi, "Food Safety Knowledge and Hygienic Practices among Different Groups of Restaurants in Muscat, Oman," Int. J. Food Sci., vol. 2020, 2020, doi: 10.1155/2020/8872981.

[8] A. E. Nardo, M. C. Añón, and A. V. Quiroga, "Identification of renin inhibitors peptides 
from amaranth proteins by docking protocols," J. Funct. Foods, vol. 64, no. November 2019, p. 103683, 2020, doi: 10.1016/j.jff.2019.103683.

[9] D. De Wrachien, "Expert Level ( Scientific Service Achievement Award )," J. Food Nutr. Heal., vol. 3, no. 1, p. 2020, 2020.

[10] A. Martinez-Lopez, M. C. Millan-Linares, N. M. Rodriguez-Martin, F. Millan, and S. Montserrat-de la Paz, "Nutraceutical value of kiwicha (Amaranthus caudatus L.)," $J$. Funct. Foods, vol. 65, no. December 2019, p. 103735, 2020, doi: 10.1016/j.jff.2019.103735.

[11] S. Chi, "Future of healthy world: Change for revolution .," J Food Nutr Heal., vol. 3, no. 1, p. 2020, 2020.

[12] U. Guide, "FoodData Central Foundation Foods Documentation and User Guide," 2019. [Online]. Available: https://fdc.nal.usda.gov/data-documentation.html.

[13] P. J. Skerrett and W. C. Willett, "Essentials of healthy eating: A guide," J. Midwifery Women's Heal., vol. 55, no. 6, pp. 492-501, 2010, doi: 10.1016/j.jmwh.2010.06.019.

[14] J. L. Lusk, "Consumer beliefs about healthy foods and diets," PLoS One, vol. 14, no. 10, pp. 1-15, 2019, doi: 10.1371/journal.pone.0223098.

[15] M. Banti, "Review on Electrical Conductivity in Food, the Case in Fruits and Vegetables," vol. 4, no. 4, pp. 80-89, 2020, doi: 10.11648/j.wjfst.20200404.11.

[16] M. W. Joanna Leeds, Regina Susan Keith, "Food and Mood: Exploring the determinants of food choices and the effects of food consumption on mood among women in Inner London," Cambridge Companion to Lit. London, vol. 9780521897, no. 1, pp. 261-278, 2011, doi: 10.1017/CCOL9780521897525.015.

[17] M. Røed, F. Nordgård Vik, E. Rudjord Hillesund, W. Van Lippevelde, and N. Cecilie Øverby, "Associations between parental food choice motives, health-promoting feeding practices, and infants' fruit and vegetable intakes: The food4toddlers study," Food Nutr. Res., vol. 64, pp. 1-11, 2020, doi: 10.29219/fnr.v64.3730.

[18] I. S, "Journal of Food Nutrition and Population Health.," J. Food, Nutr. Popul. Heal., vol. 1, no. 1, pp. 3-7, 2017, [Online]. Available: http://www.imedpub.com/articles/advanced-technologies-for-dairy-effluenttreatment.php?aid $=18637$. 